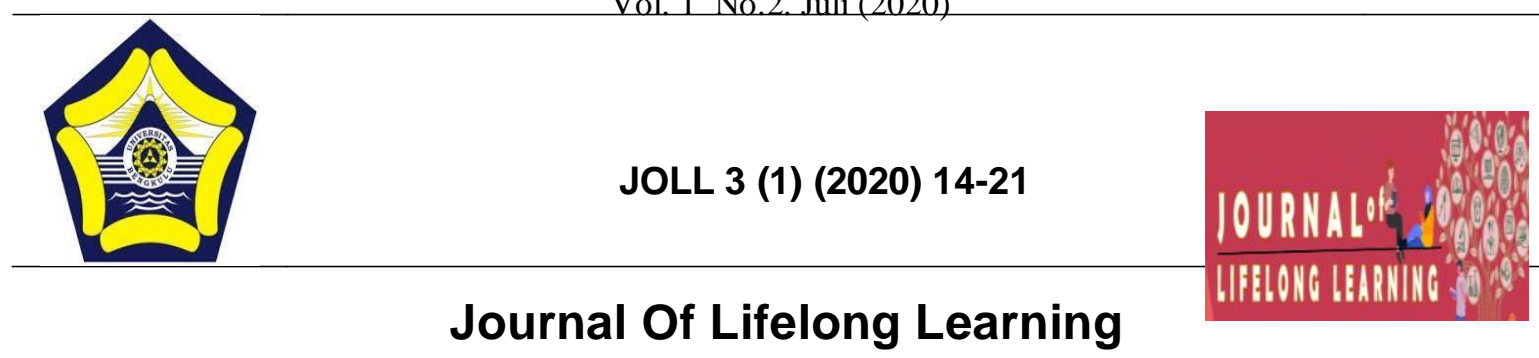

\title{
Penyaluran Lulusan Secara Langsung Semi Langsung Dan Tak Langsung Wiwin $^{1}$, Rufran Zulkarnain ${ }^{2}$, Agus Zainal ${ }^{3}$
}

${ }^{1}$ Wiwin okta dia malindo.Universitas Bengkulu. wiwinmalindo30@gmail.com

${ }^{2}$ Rufran Zulkarnain Universitas Bengkulu,Indonesia,rufranzulkarnain @yahoo.com

${ }^{3}$ Agus Zainal. Universitas Bengkulu. Aguszainal1823@gmai.com

\begin{abstract}
This thesis research uses descriptive qualitative method, the researcher acts as a nonparticipatory research subject, data collection techniques used are interviews, observation and documentation study, data equivalence is carried out by triangulation techniques. This thesis research was conducted because LKP Lubuk Akal was the only LKP in Bengkulu City that had a graduate distribution program, the distribution program for graduates at the Lubuk Akal LKP was carried out in three ways namely, 1). Direct distribution of graduates is the distribution of graduates that are planned and conducted by the head of LKP without involving other pockets, 2.) semi-direct distribution, is channeling by involving the Depnakers / BLK as the party delivering the graduates. 3). indirect distribution is distribution that involves other parties, namely intermediaries, intermediaries are usually individuals who understand and master the distribution of graduates who are skilled in sewing. Distribution of graduates at LKP Lubuk Akal has been conducted since 2016 until now, the program and the implementation of graduate distribution are conducted because the LKP chairman has moral responsibilities and obligations and his conscience is called to try to channel graduates so that LKP graduates get jobs and income.
\end{abstract}

Key words: responsibility to graduates 


\section{PENDAHULUAN}

Lembaga Kursus dan Pelatihan (LKP) Lubuk Akal memiliki fasilitas yang lengkap untuk melaksanakan ujian kompetensi sehingga Lembaga Kursus dan Pelatihan (LKP) Lubuk Akal menjadi satusatunya tempat ujian kompetensi yang ada di Kota Bengkulu. Lembaga Kursus dan Pelatihan (LKP) Lubuk Akal memiliki program unggulan dan tanggung jawab untuk menyalurkan lulusannya, data lengkap pada tabel terlampir.

Adapun Menurut Buchari Alma (2016:51) Ada tiga cara penyaluran yakni Penyaluran langsung , Penyaluran semi langsung serta penyaluran tak langsung Berdasarkan pendapat diatas peneliti menyimpulkann penyaluran merupakan proses menyalurkan lulusan atau jasa hingga sampai ke pengguna.

Berdasarkan data yang di dapat di LKP Lubuk Akal bahwa pada tahun 2017, 2018 dan 2019 lulusan berjumlah 181 orang dan 91 yang sudah tersalurkan 63 membuka usaha menjahit secara mandiri sisa $5 \%$ tidak ada informasi atau tanpa keterangan, data lengkap pada tabel terlampir. Berdasarkan latar belakang yang telah dikemukakan maka, peneliti ingin mendalami dan mendiskripsikan hal- hal yang berkaitan dengan Penyaluran Lulusan di Lembaga
Kursus Pelatihan (LKP) Lubuk Akal Kota Bengkulu. Tujuan penelitian adalah sebaga berikut:

a. Untuk mendeskripsikan penyaluran lulusan langsung yang dilakukan oleh Lembaga Kursus Pelatihan (LKP) ke penjahit Kota Bengkulu.

b. Untuk mendeskripsikan penyaluran lulusan semi langsung oleh Lembaga Kursus Pelatihan (LKP) ke Dinas Tenaga Kerja (Depnaker) sehingga warga belajar dapat di salurkan ke PT Garmen Cimahi.

c. Untuk mendeskripsikan penyaluran lulusan tak langsung melalui perantara antara Lembaga Kursus Pelatihan (LKP) ke penjahit.

\section{Metode Penelitian}

\section{a. Teknik Validasi Data}

Untuk menguji validasi data,peneliti menggunakan teknik triangulasi sebagaimana pendapat meleong (2005:33) teknik triangullasi adalah teknik pengumpulan data yang bersifat menggabungkan dari berbagai teknik pengumpulan data dan sumber data yang telah ada. Untuk lebih jelasanya ketiga bentuk trianggulasi tersebut akan dijelasakan oleh peneliti. 
a. Subjek Penelitian

Adapun subjek penelitian dalam adalah ketua Lembaga Kursus Pelatihan (LKP) Lubuk akal yakni Ibu Rosila Kamari, Ibu Dwi Lind Y. SE selaku sekretaris Lembaga Kursus Pelatihan (LKP) Lubuk Akal dan Ibu Susanti. SH selaku seksi pendidik di Lembaga Kursus Pelatihan (LKP) Lubuk Akal alasannya untuk mendapatkan data atau catatan yang tertulis mengenai penyaluran lulusan secara langsung, sehingga penyaluran warga belajar bisa berjalan hingga saat ini. Kemudian untuk mengetahui tentang penyaluran semi langsung maka peneliti mewawancarai Bapak Ari selaku staf tenaga kerja Balai Latihan Kerja (BLK) yang membantu menangani tentang penyaluran lulusan secara semi langsung. selanjutnya untuk mengetahui tentang penyaluran secara tak langsung, peneliti mewawancarai Ibu Yuniatun sebagai perantara yang di percayai untuk menyalurkan lulusan guna untuk memperoleh informasi yang lebih akurat.

\section{Hasil danPembahasan}

Sesuai dengan hasil penelitian telah peneliti lakukan terhadap subjek penelitian yaitu Ibu Rosilllah Kamari selaku ketua LKP Lubuk Akal Kota Bengkulu, sekretaris LKP Lubuk Akal dan pengajar LKP Lubuk Akal dan Bapak Ari selaku staf tenaga kerja BLK Provinsi Bengkulu bidang penyaluran lulusan, dan Ibu Yuniatun selaku perantara serta hasil studi observasi dan dokumentasi berikut dikemukakan rumusan masalah dan tujuan penelitian sebagai berikut :

1. Mendiskirpsikan penyaluran lulusan secara langsung oleh LKP ke penjahit di Kota Bengkulu.

Berdasarkan hasil penelitian terkait dengan tujuan mendiskripsikan penyaluran lulusan secara langsung oleh LKP Lubuk Akal bahwa ada perencanaan LKP berupa mempersiapkan calon lulusan (warga belajar) membuat daftar penempatan adapun langkah-langkah penyaluran yang dimuat pada pedoman penyaluran lulusan adalah sebagai berikut, penyluran dapat dilakukan secara langsung dan tahapan 1). Pemantapan oleh pengurus. 2). Mempersiapkan berkas administrasi. 3). Membuat daftar nama lulusan. 4). Staf pendidikan konfirmasi 
dengan lulusan. 5). Staf pendidik konfirmasi dengan sekretaris. yang berperan dalam menyalurkan adalah Ibu ketua LKP. LKP melakukan penyaluran secara langsung karena merasa terpanggil hati nurani untuk berbuat yang baik untuk lulusan dan juga LKP memiliki tanggung jawab moral, mental menyalurkan lulusan, lulusan ditempatkan pada 5 (lima) penjait yang ada di Kota Bengkulu seperti penjahit Ica, penjahit Ana, penjahit Aura, penjahit Danisa, penjahit Ayu.

Buchari Alma (20116:51) Penyaluran langsung adalah proses menyalurkan jasa atau industri untuk menyalurkan jasa atau barang langsung ke pengguna. Kemudian setiap lembaga pendidikan hendak memiliki program penyaluran lulusan

Ada satu hal utama yang diperoleh oleh pemilik dalam penelitian ini yaitu, ketua lembaga menggunakan hati nurani didalam mengelola LKP sehingga mendorongnya untuk melakukan penyaluran lulusan LKP, karena LKP juga memiliki tanggung jawab moral supaya lulusannya tidak menganggur.
Menurut Irmansyah Effendi ( 2002 : 97) hati nurani adalah kemampuan manusia untuk melihat kedalaman dirinya dan membedakan apa yang baik dan apa yang buruk terlepas dari segala kekurangan dan cacatnya, manusia adalah makhluk yang mampu menentukan yang baik dilakukan dan membuat keputusan berdasarkan pertimbanagannya.

Berdasarkan pendapat diatas makaa peneliti menyimpulkan bahwa hati nurani adalah dorongan dari dalam diri manusia yang tidak dipengaruhi oleh kepentingan dari luar diri manusia

Adapun menurut Muchlas Samani (2017 : 12) Tanggung jawab moral adalah kesadaran individu akan tingkah laku atau perbuatan yang disengaja maupun tidak sengaja yang tela dilakukan.

Berdasarkan pendapat diatas maka peneliti menyimpulkan bahwa tanggung jawab moral adalah kesediaan melakukan sesuatu dan menerima baik buruk akibat atas dasar kesadaran dari dalam dirinya tanpa dipengarui faktor dari luar dirinya.

Sedangkan tanggung jawab moral yang dilakukan oleh ketua LKP Lubuk Akal yakni ketua LKP Lubuk Akal 
bertanggung jawab menyalurkan lulusan walaupun tidak ada perintah dari pihak manapun dan penyaluran ini merupakan tanggung jawab yang dilaksankan oleh LKP Lubuk akal agar lulusan dapat bekerja.

\section{Mendiskirpsikan}

penyaluran

lulusan secara semi langsung oleh LKP ke Depnaker sehingga lulusan dapat tersalurkan ke PT Garmen.

Berdasarkan hasil penelitian dengan subjek penelitian dan temuan penelitian dilapangan terkait dengan tujuan mendiskripsikan penyaluran lulusan secara semi langsung yang dilakukan oleh LKP Lubuk Akal ada perencanaan berupa mempersiapkan calon lulusan dan berkoordinasi dengan bagian penyaluran lulusan pada BLK ada tahapan yang dilaksanakan oleh pihak LKP. 1). Pemantapan oleh pengurus. 2). Penyiapan berkas administrasi lulusan. 3). Sekretaris membuat daftar nama lulusan yang akan disalurkan. 4). Daftar nama lulusan diirim ke BLK. 5). BLK / Depnakers mengeluarkan surat keterangan penyaluran. 6). Lulusan disalurkan oleh BLK / Depnakers. Adapun yang berperan melakukan penyaluran lulusan semi langsung adalah ketua LKP dan Bapak Ari sebagai pegawai BLK pada bagian penyaluran lulusan, LKP menyalurkan lulusan secara semi langsung karena memiliki tanggung jawab moral terhadap lulusan dan juga di dukung oleh program dari BLK untuk menyalurkan lulusan. Lulusan di tempatkan pada PT Garmen yang ada di Cimahi, faktor penghambatnya yaitu tidak setiap saat ada permintaan dari PT Garmen, faktor pendukungnya yaitu kesiapan dan keterampilan lulusan untuk siap di tempatkan.

Buchari Alma (20116:51) Penyaluran semi langsung adalah proses menyalurkan jasa melalui saluran lembaga. Peneliti dapat menyimpulakan bahwasanya penyaluran secara semi langsung yakni proses untuk menyalurkanlulusan melibatkan pihak lemabaga.

Salah satu penting dalam penyaluran lulusan secara semi langsung ini adalah kemampuan dan kesediaan pengelola LKP untuk selalu berkomunikasi dan juga pihak BLK selalu update tentang perushaan atau tempat menjahit yang siap menerima lulusan. 
3. Mendiskirpsikan

penyaluran lulusan secara tak langsung melaluui prantara antara LKP dan penjahit .

Berdasarkan hasil penelitian dilapangan terkait dengan tujuan mendiskripsikan penyaluran lulusan secara tak langsung yang dilakukan oleh perantara antara LKP lubuk akal bahwa ada taapan. 1). Pemantapan oleh pengurs. 2). Sekretaris membuat daftar nama lulusan. 3). Peranatara menerima berkas lulusan. 4). Perantara melakukan konfirmasi dengan penerima. 5). Perantara membantu proses penyaluran. Adapun yang dilakukan oleh LKP dan yang berperan dalam penyaluran ini adalah ketua LKP dan perantara yaitu Ibu Yuniatun, LKP menyalurkan lulusan tak langsung juga karena keterpanggilan pekerjaan. Lulusan ditempatkan pada penjahit yang ada di Kota Bengkulu, faktor penghambatnya terkadang saat warga belajar lulusa tapi pihak pengguna belum siap menerima, sedangkan faktor pendukungnya yaitu para lulusan siap untuk ditempatkan dan juga memiliki keterampilan menjahit yang baik.
Buchari Alma (20116:51)

Penyaluran tak langsung adalah proses penyaluran jasa lebih dari satu. Maka dapat dikatakan bahwasanya penyaluran secara tak langsung yakni proses untuk menyalurkanlulusan melibatkan prantara satu atau pihak lainnya.

Ada satu hal yang harus dimiliki oleh pengelola LKP dalam penyaluran lulusan secara tak langung ini yaitu, kemampuan ketua LKP untuk siap dan dan berkoordinasi dengan pihak manapun guna penyaluran lulusan, salah satunya karena LKP hendaknya dapat bekerja sama dengan pihak perantara, yang penting dijaga bahwa perantara tersebut berkompeten, jujur dan dapat dipercaya dalam penyaluran.

\section{Kesimpulan}

Dari hasil penelitian tentang penyaluran lulusan LKP Lubuk Akal Kota Bengkulu yang beralamatkan Jl. Flamboyan Raya No. 1B Kel. Kebun Kenanga Kec. Ratu Agung, berdasarkan tujuan peneltian, hasil penelitian dan pembahasan maka dapat disimpulkan.

Pertama, Berdasarkan temuan penelitian terkait dengan tujuan mendiskripsikan penyaluran lulusan secara langsung oleh LKP Lubuk Akal bahwa ada perencanaan LKP berupa mempersiapkan 
calon lulusan (warga belajar) membuat daftar penempatan dan ada langkahlangkah atau tahapan yang dilakukan, yang berperan dalam menyalurkan adalah Ibu ketua LKP.

Ada satu hal utama yang diperoleh oleh pemilik dalam penelitian ini yaitu, ketua lembaga memiliki hati nurani didalam memanjemen LKP sehingga mendorongnya untuk melakukan penyaluran lulusan LKP, karena LKP juga memiliki tanggung jawab moral supaya lulusannay tidak melanggar.

Kedua, Berdasarkan hasil wawancara peneliti dengan subjek penelitian dan temuan penelitian dilapangan terkait dengan tujuan mendiskripsikan penyaluran lulusan secara semi langsung yang dilakukan oleh LKP Lubuk Akal ada perencanaan berupa mempersiapkan calon lulusan dan berkoordinasi dengan bagian penyaluran lulusan pada BLK ada tahapan yang dilaksanakan oleh pihak LKP, yang yang berperan melakukan penyaluran lulusan semi langsung adalah ketua LKP dan Bapak Ari sebagai pegawai BLK pada bagian penyaluran lulusan, LKP menyalurkan lulusan secara semi langsung karena memiliki tanggung jawab moral terhadap lulusan dan juga di dukung oleh program dari BLK untuk menyalurkan lulusan. Lulusan di tempatkan pada PT Garmen yang ada di Cimahi, faktor penghambatnya tidak setiap saat ada permintaan dari PT Garmen, faktor pendukungnya kesiapan dan keterampilan lulusan untuk siap di tempatkan.

Salah satu penting dalam penyaluran lulusan secara semi langsung ini adalah kemampuan dan kesediaan pengelola LKP untuk selalu berkomunikasi dan juga piak BLK selalu update tentang perushaan atau tempat menjahit yang siap menerima lulusan

Ketiga, Berdasarkan hasil penelitian dilapangan terkait dengan tujuan mendiskripsikan penyaluran lulusan secara tak langsung yang dilakukan oleh perantara antara LKP lubuk akal bahwa ada perencanaan berupa mempersiapkan warga belajar calon lulusan untuk siap ditempatkan dan ada koordinasi dengan perantara yang akan membawa lulusan ketempatnya bekerja, terhadap yang dilakukan oleh LKP dan yang berperan dalam penyaluran ini adalah ketua LKP dan perantara yaitu Ibu Yuniatun, LKP menyalurkan lulusan tak langsung juga karena keterpanggilan pekerjaan. Lulusan ditempatkan pada penjahit yang ada di Kota Bengkulu, faktor penghambatnya terkadang saat warga belajar lulusa tapi pihak pengguna belum siap 
menerima, sedangkan faktor pendukungnya para lulusan siap untuk ditempatkan dan juga memiliki keterampilan menjahit yang baik.

\section{Referensi}

Alma, Buchari (2007). Menenjemen pemasaran dan pemasaran jasa. Bandung. Alfabeta

Depdiknas. (2002). Kamus Besar Bahas Indonesia. Jakarta: Balai Pustaka

Depdiknas. (2003).Undang- undang RI No.20 tahun 2003 Tentang System Pendidikan Nasional. Depdiknas. Jakarta.

Effendi, Irmansyah.(2002). Hati Nurani. Jakarta. PT Gramedia Pustaka Utama Emzir. (2011). Metode Penelitian Kualitatif Analisis Data. Jakarta. Rajawali Pers.

Fuad, Anis \& Sapto Kandung (2014). Panduan Praktis Penelitian Kualitatif. Yogyakarta. Graha Ilmu.

Haspari, M.I. 2017. Pengkajian Program Pariwisata. Jurnal Ilmiah VISI PGTK PAUD dan DIKMAS. 12(1): 53-66

Joseoef, Soelaiman (1992). Konsep Dasar Pendidikan Luar Sekolah. Jakarta: Bumi Aksara berkompeten, jujur dan dapat dipercaya dalam penyaluran.

Kementrian Tenaga Kerja dan Transmigrasi, Direktoral Jendral Pembinaan Penempatan Tenaga Kerja dan Peluasan Kesempatan Kerja. Pedoman Penyaluran Lulusan (03 : 2018)

Moleong, Lexy J. (2017) Metode Penelitian Kualitatif. Bandung PT Remaja Rosdakarya Offset.

Marzuki Saleh, (2012). Pendidikan Nonformal Dimensi Keaksaraan Fungsional Pelatihan Andragogi. Bandung. PT Remaja Rosdakarya.

Mustofa, Kamil. (2007). Model Pendidikan dan Pelatihan Konsep dan Aplikasi. Bandung: Alfabeta

Saroso, Sumiaji (2017). Penelitian Kualitatif Dasar-Dasar. Jakarta Barat. Indeks Samani, Muchlas (2017). Pendidikan Karakter. Jakarta. Indonesia Hertige 